\title{
Die kerk en mense op straat in die informele behuisingsgebiede in Mangaung/Bloemfontein
}

\begin{abstract}
Author:
Pieter Verster ${ }^{1}$

Affiliation:

${ }^{1}$ Department of Missiology, University of the Free State, South Africa

Correspondence to:

Pieter Verster

Email:

versterp@ufs.ac.za

Postal address:

PO Box 29115, Danhof 9310

South Africa

Dates:

Received: 12 Oct. 2010

Accepted: 24 Mar. 2011

Published: 31 May 2011

How to cite this article: Verster, P., 2011, 'Die kerk en mense op straat in die informele behuisingsgebiede in Mangaung/Bloemfontein', Verbum et Ecclesia 32(1), Art. \#466, 8 pages. doi:10.4102/ ve.v32i1.466

\section{Note:}

This article is based on research supported by the NRF of South Africa. All opinions, conclusions and recommendations made are the opinion of the author and the NRF does not accept responsibility for it. The research was also supported by the university's cluster, 'New Frontiers in poverty reduction and sustainable development'.
\end{abstract}

C 2011. The Authors. Licensee: OpenJournals Publishing. This work is licensed under the Creative Commons Attribution License.
The challenges posed by informal settlements are enormous, also in the Bloemfontein/ Mangaung area. The question asked in this article was how the church can reach out to people on the streets and in the informal settlements. Research was conducted to establish the views of the church and the task it has from randomly approached people on the streets. The Bible speaks positively on the task of the people of Israel and the church to reach out to foreigners. The church in informal settlements should see the people on the streets as its responsibility. A very important aspect is to gain structures in the informal community for the churches to be present in a more concrete way. Although the church remains the people of God and is not limited to structures, the presence of structures can in many ways enhance the positive help and influence of the church in the community; even to the people on the streets.

\section{Inleiding}

Informele behuisingsgebiede naby Mangaung/Bloemfontein vermeerder soos paddastoele. Die uitdagings wat die gebiede bied aan die verkondiging van die evangelie en die werk van die kerk is uiters groot. Navorsing in die gebiede toon aan dat die kerk in al sy verskillende vorme en verbande tog teenwoordig is en ook 'n beduidende rol speel. Die onderlinge verhouding van lidmate toon aan dat broeder- en susterskap van die gemeentes juis onder sulke omstandighede sinvol is. Wat is egter die houding van mense op straat oor die kerk en die teenwoordigheid van die kerk? Die kerk het ook 'n rol om te vervul in die gemeenskap; hierdie rol is van groot belang.

\section{Navorsingsvrae}

Om te bepaal wat die rol van die kerk is en moet wees, is sekere vrae in die gemeenskap aan mense gerig. In die ondersoek is gepoog om te bepaal wat die houding teenoor die kerk is. Hoe lyk die bestaan van mense op straat onder sulke omstandighede? Behoort die mense op straat aan die kerk? Wat is hulle houding teenoor die kerk? Wat doen die kerk vir hulle? Wat is hulle verwagtinge van die toekoms? Hierdie navorsing moet daartoe lei dat sekere beginsels vasgelê word waardeur die kerk sy rol beter kan vervul. Daarom moet daar ook gevra word hoe die kerk vir mense in informele gebiede hoop kan skep.

\section{Metodologie}

Kwalitatiewe navorsing bied onteenseglik besondere moontlikhede om houdings te bepaal. Patton (2002) skryf in hierdie verband:

Qualitative inquiry - strategically philosophically, and therefore, methodologically - aims to minimize the imposition of predetermined responses when gathering data. It follows that questions should be asked in a truly open-ended fashion so people can respond in their own words. [Kwalitatiewe ondersoek - strategies filosofies en daarom, metodologies - poog om die oplegging van voorafbepaalde reaksies te verminder wanneer inligting versamel word. Dit beteken dat vrae op ' $n$ werklike oop wyse gevra moet word sodat mense in hulle eie woorde kan reageer.]

(Patton 2002:353)

Die navorsing het gepoog om sinvolle gevolgtrekkings te maak oor sentrale sake wat na vore kom sonder om te veralgemeen. Nieuwenhuis (2007) toon duidelik aan hoedat die gevolgtrekkings gemaak word:

Qualitative data analysis is usually based on an interpretative philosophy that is aimed at examining the meaningful and symbolic content of qualitative data. Phrased differently, it tries to establish how participants make meaning of a specific phenomenon by analysing their perceptions, attitudes, understanding, knowledge, values, feelings and experiences in an attempt to approximate their construction of the phenomenon. [Die evaluering van kwalitatiewe inligting is gewoonlik gebaseer op ' $n$ interpretatiewe filosofie wat na die ondersoek van betekenisvolle en simboliese inhoud van kwalitatiewe inligting streef. Anders uitgedruk, probeer dit vasstel hoe deelnemers betekenis vorm van ' $n$ spesifieke fenomeen deur hulle 
persepsies, houdings, verstaan, kennis, waardes, gevoelens en ervarings te analiseer in ' $n$ poging om te hulle konstruksie van die fenomeen te begryp.]

(Nieuwenhuis 2007:99)

Deur middel van kwalitatiewe navorsing word gepoog om 'n beeld te verkry van enkele persone op straat se houding teenoor die kerk. Ten spyte van die feit dat daar nie veralgemeen kan word nie, kan daar tog duidelike tendense in die houdings waargeneem word. Hierdie tendense kan sinvol verken word en bydrae tot die proses waartydens die kerk bepaal hoe hy verder moet voorgaan in sy bediening in die informele gebiede. Die inligting wat verkry word, word nie bepaal deur die grootte van die steekproef nie, maar uit die sinvolheid van die response. Patton (2002) verduidelik:

\begin{abstract}
The validity, meaningfulness, and insights generated from qualitative inquiry have more to do with the information richness of the cases selected and observational/analytical capabilities of the researcher than with sample size. [Die geldigheid, betekenis en insigte wat kwalitatiewe ondersoek genereer het meer te make met die rykdom van inligting van die gekose sake en die waarneming/analitiese vermö̈ van die navorser as met die grootte van die steekproef.]
\end{abstract}

(Patton 2002:245)

Hierdie navorsing word veral betekenisvol wanneer dit binne die raamwerk van deelnemende aksie navorsing (Participatory Action Research) geplaas word. Altrichter et al. (2002:130) stel die uitgangspunt van dié navorsing duidelik: 'Action research is enquiry with people, rather than research on people' [Aksie navorsing is ondersoek saam met mense eerder as oor mense]. In hierdie proses word nie alleen die deelnemers se houdings hanteer nie, maar die navorser self ook in die proses van aksie wat geneem word verander (2002:131). Dit is verder deursigtig en verantwoordbaar, omdat die proses openbaar is (2002:131). In hierdie proses speel die kwadraat van kennis 'n belangrike rol. In die navorsing kan die navorser hom- of haarself ook van die kwadraat van kennis bedien. Mukhala \& Groenewald (1998:5,6) verwys na die betekenis van die vier kwadrante van kennis in deelnemende aksie navorsing. Die navorser self en die gemeenskap waaronder navorsing gedoen word is nie twee teenoorstaande groepe nie.

Die eerste kwadrant word bepaal deur die uitgangspunt:

- ons weet

- hulle weet.

Die tweede kwadrant deur die uitgangspunt:

- ons weet nie

- hulle weet.

Die derde kwadrant deur die uitgangspunt:

- ons weet

- hulle weet nie.

Die vierde kwadrant deur die uitgangspunt:

- ons weet nie

- hulle weet nie.

Dit beteken dat daar in die navorsing beweeg word van 'n situasie waar beide die navorser en die gemeenskap nie oor die kennis beskik nie, verby die situasie waar die gemeenskap oor die kennis beskik en die navorser nie, of waar die navorser oor die kennis beskik en die gemeenskap nie, na die situasie waar albei die navorser en die gemeenskap saam oor die kennis beskik.

In hierdie navorsing is daar gepoog om juis die mense op straat te laat praat, sodat aksie geneem kan word en die kerk betrokke kan raak by die gemeenskap self.

\section{Die begrip: Mense op straat}

Die straat is ' $n$ begrip wat met die stad saamhang; in die stad leef die mense op straat. Hulle beweeg daagliks bymekaar verby. Hulle beweeg tussen hul wonings of skuilings waar hul tuis is na die gemeenskap rondom hulle. Op straat is daar geen onderskeid tussen gelowiges en ongelowiges nie, soos in die kerk nie, almal leef saam en skuur met mekaar skouers. Daar is ook nie inhibisies op straat nie. Mense hoef nie voor te gee dat hulle beter as ander is nie. Hulle kan ook eerlik wees oor hulle beskouing oor die kerk, anders as in die kerk waar hulle dikwels ander se gedagtes in ag moet neem. Daar is geen beletsel op hulle eie opinie nie. Vir die kerk is dit uiters belangrik om waar te neem wat mense op straat dink daarvan. Die mense op straat is in baie gevalle vreemdelinge vir die kerk. Die begrip 'vreemdeling' word dus ruim gebruik om almal wat buite die kerk teëgekom word aan te dui. Dit sluit natuurlik ook buitelandse persone wat teenwoordig is in, maar dit dui hier op die begrip van almal wat aanvanklik nie direk deur die kerk bedien word nie. God se trou en sorg wat ook die vreemdeling insluit is van groot belang wanneer mense buite die kerk benader word. Die wyse waarop Israel opgeroep word om die vreemdeling met respek te hanteer beklemtoon juis God se liefde vir diegene wat hulle nie kan beroep op regte wat deur die gemeenskap aan hulle toegeken word nie. Dit is God self wat vir hulle intree. Diegene wat in die Bybel buite die volk van God voorgekom het, word as vreemdelinge aangedui en daarom is dit goed om die Bybelse hantering van die begrip vreemdeling na te gaan.

Diegene wat in die Bybel buite die volk van God voorgekom het word as vreemdelinge aangedui en daarom is dit goed om die Bybelse hantering van die begrip 'vreemdeling' na te gaan.

\section{Die kerk en die vreemdeling}

Die begrip vreemdeling is bekend in die Ou Testament, waar God van sy volk eis om reg te doen aan die vreemdeling. Die swakke, naamlik die wees en weduwee en die vreemdeling word dikwels saam genoem.

Deuteronomium 5:12-15 bevestig dat die Here van die volk vra om te rus op die Sabbatdag omdat hulle uit Egipte gelei is; dat hulle slawe in Egipte was, dat die Here hulle daaruit bevry het en dat hulle daarom moet rus en ook die vreemdelinge by hulle. Daardie sorg van die Here vir sy volk sluit ook die vreemdeling in. Die Sabbatdag is dus 'n teken van God se versorging van sy volk en van die rus waaruit hy 
hulle gelei het uit die slawerny waarin hulle was, maar die vreemdeling by hulle moet ook rus omdat hulle saam die rus van God beleef. Kalland (1992:55) wys daarop dat hier juis sorg vir die mindere groepe in die samelewing beklemtoon word. Dit handel oor lewe en dood en die volk van God wat gehoorsaam moet lewe in die spanning wat voorkom sodat die verlossing van God ook gestalte kry (Miller 1990:74).

Die kerk kan dus nie afsydig staan teenoor diegene wat niegelowig is nie, maar moet hulle ook bereik en in die heil van die lewe met God insluit.

Levitikus 19 bevestig dat die Here die God is van die hele gemeente van Israel, dat hulle heilig moet wees omdat die Here God heilig is. In vers 33 word die saak baie sterk beklemtoon dat die vreemdeling by die volk in die land waar hulle woon nie onderdruk mag word nie, maar dat hulle vreemdelinge soos mede-burgers moet behandel en moet liefhê soos hulleself, omdat hulle self immers ook vreemdelinge in Egipte was. 'Ek is die Here julle God', word beklemtoon. God verbind die sorg vir die vreemdeling aan die feit dat hy die Here is wat die verlossing bewerk. God se liefde vir die sondaar en veragte is duidelik, sodat op grond van die teksgedeelte dit nie nodig sou wees vir die wetgeleerde om vir Jesus te vra wie sy naaste is nie (Harris 1990:609). Hartley (1992) stel dit indrukwekkend:

Since aliens are ignorant of local customs, standards, prices, etc., and since they have little recourse in a dispute except for the honor of the host people, they are subject to all kinds of schemes devised to take advantage of them. Israelites, however, are to have special regard for strangers. [Aangesien vreemdeling onkundig is oor plaaslike gebruike, standaarde, pryse ensovoorts en hulle hul op weinig anders as die eer van hul gashere kan beroep, word hulle uitgelewer aan allerhande soorte skemas wat uitgedink word om hulle uit te buit. Israeliete moet egter besondere respek vir vreemdelinge hê.]

(Hartley 1992:322)

Hulle moet dus ook die ander liefhê soos hulle hulleself liefhet: 'This command to love is motivated by Israel's remembering that they have been resident aliens in Egypt. This motivation underscores the common human bond between aliens and Israelites' [Hierdie opdrag om lief te hê word gemotiveer deur die herinneringe van Israel aan die feit dat hulle self ook vreemdelinge in Egipte was. Hierdie motivering beklemtoon die feit dat die vreemdelinge en Israeliete 'n gemeenskaplike medemenslikheid deel.] (Hartley 1992:322).

Die kerk sal dus die buitengewone sorg van God vir diegene wat hulle die minste kan beroep op kulturele óf ekonomiese óf ander regte moet beklemtoon in die hantering van die nood van hulle wat buite die kerk staan.

In Eksodus 22:21 word daar ook bevestig dat die vreemdeling nie verdruk of swaar mag kry nie, want die volk was self vreemdelinge in Egipte. So het hulle die heil van God beleef in Egipte en moet hulle dit ook erken. Ook in Eksodus 23:9 word dit verder beklemtoon dat die vreemdeling nie verdruk mag word nie, want hulle ken die lewe van 'n vreemdeling omdat hulle self vreemdelinge in Egipte was. Durham (1987:328) bevestig: 'Concern for the disprivileged and humanitarian sensitivity are reflected throughout the OT, in every major dimension of its teaching' [Besorgdheid oor die minderbevoorregtes en sensitiwiteit vir mense word regdeur die $\mathrm{Ou}$ Testament, in al die belangrikste leerstellings, vertoon].

Esegiël 22:7 bevestig dat die vader en moeder en die vreemdeling verdruk word, asook dat die weeskind en die weduwee mishandel word; juis om hierdie rede sal die Here sal die oordeelsdag bring. Hy sorg en waak oor die lewe van die arme, die vreemdeling en die persoon wat sonder regte is. In vers 29 word daar dan ook bevestig dat die burgers van die land mense verdruk en beroof, armes in nood uitbuit en die vreemdeling verdruk asof daar geen reg bestaan nie. Die persoon wat buite die gemeenskap is mag nie verdruk of verag word nie, maar moet ook versorg en gehelp word. Die toets is hoe mense met geen stem behandel word (Allen 1990:36).

Ook in Sagaria 7:10 word bevestig dat die weduwee en die weeskind, die vreemdeling en die arme nie verdruk moet word nie en dat bose planne nie teenoor mekaar gevorm mag word nie. God waak dus steeds oor die reg van sy volk, maar ook oor die reg van hulle buite die volk, omdat hulle self vreemdelinge in Egipte was. Die klem val op geregtigheid en God wat waak oor waarheid en liefde en wat sorg (Smith 1984:225).

Ook Maleagi 3:5 bevestig dat die Here as regter sal optree en dat hy sal oordeel as sy volk sou optree teen die vreemdeling en die vreemdeling verdring, aangesien hulle dan daardeur sal toon dat hulle nie eerbied vir die Here het en die Here erken nie (Smith 1984:330).

Waar die nie-gelowige of die nie-kerklike verdruk word sal die kerk ook die liefde van God moet vertoon en so die nood van die persoon hanteer.

In die Nuwe Testament is dit veral die gelykenis van die Barmhartige Samaritaan (Luk 10:25-37) wat ten sterkste beklemtoon dat omgee baie belangrik is vir die kerk van Jesus Christus. Indien 'n mens Jesus wil navolg moet dit op so 'n wyse gedoen word dat omgee sigbaar word op die wyse waarop daar met hom gelewe word. Navolging van Christus beteken dat jy ' $n$ naaste sal wees vir ander en dat jy sal uitreik na die naaste juis om so 'n persoon te kan help. In hierdie gelykenis is die verskillende aktante baie duidelik en die kern waaroor dit gaan is juis die versorging van die gewonde persoon deur die vreemdeling. In hierdie gelykenis word die rolle dus omgekeer met die dringende boodskap dat die vreemdeling self God se guns kan verkry. Vir die mense op straat is dit dus uiters belangrik dat die omgee gedagte sterk beklemtoon sal word.

Ook in Lukas 4:16-32 word daar deur die verskillende aktante in daardie gebeurtenis beklemtoon dat Jesus as Messias heil bring, maar nie daarvoor erken word nie. Hoe tree hy as Messias op? Deur om te gee en om te sien na die persoon in nood. Liefeld (1984) stel dit soos volg:

In summary, Luke presents the quotation and Jesus' ensuing comments as a programmatic statement of Jesus' ministry. 
As prophet and Messiah, he will minister to the social outcasts and needy, including Gentiles, in the power of the Spirit. [Opsommenderwys bied Lukas die aanhaling en Jesus se daaropvolgende opmerkings as die beslissende stelling aangaande Jesus se bediening aan. Hy sal in die krag van die Gees, as profeet en Messias, die randfigure en behoeftiges bedien.]

\section{(Liefeld 1984:867)}

Deur vrylating vir die gevangenis en sig vir die blindes aan te kondig en uit te reik sodat die evangelie aan die armes verkondig kan word, word omgee 'n baie besonderse saak wat beklemtoon word in die evangelies. Guthrie (1981:512) is van mening dat dié gedeelte juis die sleutel tot Jesus se optrede van prediking en genesing is. Nolland (1989) toon aan dat Jesus self die beginsel van omgee voorop stel:

The Lukan Jesus is no social reformer and does not address himself in any fundamental way to the political structures of his world, but he is deeply concerned with the literal, physical needs of men (Acts 10:38), as with their directly spiritual needs. [Jesus in Lukas is nie ' $n$ sosiale hervormer nie en rig homself nie op 'n fundamentele wyse tot die politieke strukture van sy wêreld nie, maar Hy is diep begaan oor die letterlike fisiese behoeftes van die mens (Hand.10:38), soos ook oor hulle direkte geestelike behoeftes.]

(Nolland 1989:197)

Ook vir Paulus is dit van groot belang dat, alhoewel hy die volk roep om gered te word uit 'n krom en verdraaide geslag en hulle gered word om die Here te dien, hy hulle oproep om steeds betrokke te wees om die evangelie binne hierdie gemeenskappe waar hulle lewe uit te dra. Die evangelie is die boodskap wat gebring moet word sodat mense hierdie woord kan hoor en die volle evangelie kan aanhoor en beleef. Schreiner (2001) stel dit duidelik:

Paul does not expect life in this world to be heaven on earth, but he does expect believers to be good citizens, to give generously to the poor, to live in society in such a way that features their Christian faith and to have families that are pleasing to God. Paul does not endorse a private Christianity, where one's individual salvation does not affect public living. New life in Christ embraces and touches every dimension of the life of believers. The blessing promised to Abraham is worked out in new relationships and new attitudes in the social sphere. [Paulus verwag nie dat die lewe in hierdie wêreld hemel op aarde sal wees nie, maar hy verwag wel van gelowiges om goeie burgers te wees, om vrygewig aan die armes te gee, om in die samelewing te leef op ' $n$ wyse waarin hulle Christelike geloof funksioneer en om gesinne te hê wat vir God aanneemlik is. Paulus staan nie 'n private Christendom, waar elke individu se verlossing nie ook die openbare lewe raak nie, voor nie. Die nuwe lewe in Christus sluit in en raak elke dimensie van die lewe van gelowiges aan. Die seën wat aan Abraham beloof is, vind neerslag in nuwe verhoudings en in nuwe houdings in die sosiale sfeer.]

(Schreiner 2001:451)

Die evangelie is die heil wat in die gemeenskap gebring moet word sodat hulle as gemeenskap dan saam in hierdie omgee van heil kan lewe. God se geregtigheid is nie vreemd soos die van die Romeinse Ryk nie (Elliott 1995:195). Dit is vir Paulus die geregtigheid van liefde in Jesus Christus en sluit selfverloëning in. Cassidy (2001:187) verduidelik dit soos volg: 'Certainly Paul's writings testify to his conviction that faithful Christian discipleship inevitably involved a dying to self' [Paulus se geskrifte getuig ongetwyfeld van sy oortuiging dat getroue Christelike dissipelskap die onafwendbare afsterwe van die self beteken].

Die versoening is essensieel in dié verband. Kim (2002) wys daarop hoedat dit juis God is wat die mens herstel:

... it is not God who needs to be reconciled to human beings,
but it is human beings who need to be reconciled to God; and
it is not by repentance, prayers, or good works on the part of
the human beings that reconciliation is brought about between
God and human beings, but it is by his grace that God reconciles
human beings to himself. [... dit is nie God wat met mense versoen
hoef te word nie, maar dit is mense wat met God versoen moet word; en
dit is nie deur bekering, gebed of goeie werke aan die kant van die mense
wat versoening tussen God en mense bewerkstellig word nie, maar dit
is deur sy genade wat God mense met himself versoen.]

(Kim 2002:217)

Hierdie versoening stempel die hele evangelie. Dit beteken ook dat die volle heil van God na almal uitreik.

Dit is in die Nuwe Testament waar God se groot barmhartigheid vir hulle wat swaarkry en gebuk gaan onder verskeie probleme soos veragting, ekonomiese nood, sonde en siektes, sterk beklemtoon word en deur die geloofsgemeenskap aan hierdie mense vertoon moet word. Nooit mag die saak van die vreemdeling nie ook die saak van die kerk word nie.

\section{Mangaung/Bloemfontein en omgewing}

Die huidige regering in Suid-Afrika word gekonfronteer met die werklikheid dat informele gebiede steeds groei en dat dit vir die voorsienbare toekoms in die SuidAfrikaanse gemeenskap teenwoordig sal wees. Die munisipaliteit van Bloemfontein aanvaar ook dat baie mense skuiling en woonplek sal vind in informele gebiede (Mokoena \& Marais 2008:109). In die afgelope tien jaar is 32263 staanplekke uitgesit in die nuut geformaliseerde gebied (Mokoena \& Marais 2008:109). Mokoena \& Marais (2008:111) wys verder daarop dat die ad hoc hantering van subsidies, talle administratiewe probleme en 'n klem op 40 vierkantemeter wooneenhede groot druk plaas op die plaaslike owerhede ten opsigte van langtermyn beplanning, plaaslike verantwoording en finansiële haalbaarheid. Die groot bevolkingsgroei lei daartoe dat stedelike gebiede 'n groot tekort aan behuising vertoon; talle mense beweeg van die platteland na die stede en bevind hulleself dikwels in uiters moeilike omstandighede. Stedelike owerhede moet dus uitermatig voorsorg tref om vir die invloei van die inwoners voorsiening te maak (Melao 2003:91). Weens die hoë koste van behuising moet daar dikwels gepoog word om die bevolkingsdigtheid ook hoog te hou (Melao 2003:91). Die informele gebiede om Bloemfontein bied dus groot uitdagings vir die regering, plaaslike owerhede en ook vir die kerk.

\section{Armoede en nood}

Die begrip 'vulnerability' [kwesbaarheid] word voorgestel as begrip om die begrip armoede te vervang (Coetzee 2002:5). 
Alhoewel 'vulnerability' [kwesbaarheid] en armoede verwant is, kan dit tog gebruik word om te verwys na iemand wat verwond is, maar nie finansieel arm nie. Dit is egter 'n nuttige begrip om die algemene afhanklikheid en nood van mense uit te druk:

A focus on vulnerability, therefore, allows for the development of a framework that goes beyond the particular situational conditions or status of individuals and households at any given moment. It recognizes the processes involved in the construction of well-being. It acknowledges the multiple agents and sites through which relative living conditions are re-negotiated in an ongoing way. [Die fokus op kwesbaarheid skep dus die geleentheid om ' $n$ raamwerk wat ruimer is as die die spesifieke voorwaardes of status van die individu en huishoudings op 'n gegewe oomblik te ontwikkel. Die proses wat die welwese van mense onderlê, word erken. Dit beklemtoon die verskeidenheid van agente en ruimtes waardeur die lewensomstandighede opnuut op 'n nuwe wyse hersien word.]

(Coetzee 2002:5)

Stedelike armoede is ' $n$ wêreldwye probleem en Tacoli et al. (2008) is van mening dat dit dikwels onderskat word weens die feit dat daar nie voorsiening gemaak word vir die stedelike situasie soos die hoër lewenskoste in die stad of onvoldoende meetinstrumente, soos byvoorbeeld oor vlakke van sanitasie nie:

Large sections of the urban population in developing countries are malnourished, have below poverty-line incomes, and face high infant and child mortality rates and large preventable disease and injury burdens. [Groot gedeeltes van die stedelike bevolking in onderontwikkelde lande is ondervoed, het inkomstes onder die armoede-vlak en word bedreig deur hoë baba- en kindersterftes, asook die hoë voorkoms van voorkombare siektes en beserings.]

(Tacoli et al. 2008:39-40)

Swanepoel \& De Beer (2006:9) wys op die sirkelgang waarin die massas mense in Afrika vasgevang is: 'In fact, the tendency exists for poverty to constantly reintroduce itself in new guises, thus ensuring that the equilibrium of ill-being continues' [Die tendens bestaan inderdaad dat armoede sigself voortdurend op 'n nuwe wyse voortdra en daardeur verseker dat die ellende bly voortbestaan].

\section{Navorsing oor mense op straat}

Kwalitatiewe navorsing is gedoen deur 18 mense op straat in die informele gebiede in Mangaung lukraak te ondervra. Ds. Tladi Maile het oop onderhoude in Sotho gevoer en dit is deur hom getranskribeer en vertaal. Vrae wat as riglyn gebruik is, het ten doel gehad om eerstens te bepaal hoe die respondente die situasie in die informele gebiede beleef; of hulle wel aan 'n kerk behoort; wat die kerk doen; wat die kerk moet doen en laastens wat die toekoms in die informele gebiede vir hulle inhou. In die ontmoeting met die mense op straat, word naas kerklidmate ook verskeie vreemdelinge vir die kerk aangetref. Die Bybelse beginsels ten opsigte van vreemdelinge is dus ook van belang vir diegene wat op straat teëgekom word. In kwalitatiewe navorsing moet juis na die stem van hulle wat op straat teëgekom word geluister word. Deur na die verskillende stemme te luister kan die kerk bepaal op watter wyse dit betrokke moet raak by die mense op straat, die vreemdeling, die wat moontlik afvallig geword het en soekende is.

\section{Response van mense op straat}

Ten opsigte van die response wat verkry is van die mense op straat is dit duidelik dat die omstandighede in die informele behuisingsgebiede steeds haglik is; mense moet met geringe inkomste steeds probeer om hulle self te onderhou.

\section{Die omstandighede in die informele gebiede}

In die ondersoek na hoe inkomste verkry word, toon verskeie van die respondente aan dat hulle deur middel van tydelike werk inkomste verkry. Daar is egter ook' $n$ beduidende groep wat aantoon dat hulle geen werk het nie. Dit is ' $n$ situasie wat net eenvoudig nie volhoubaar is nie. Die kerk sal hierin ook 'n besondere bydrae moet lewer. Mense wat op straat teëgekom is, toon dus aan dat hulle nie in staat is om hulle self te onderhou vanweë die gebrek aan nodige werk nie.

\section{Lidmaatskap van die kerk}

Sommige respondente wat op straat teëgekom is, het wel aangedui dat hulle aan 'n kerk behoort. Dit bevestig dat die kerk in verskillende gestaltes in die informele gebiede teenwoordig is. Op grondvlak en by die mees afgeleë plakkershuisie in die informele gebiede is daar mense teenwoordig wat aan een of ander kerk behoort of op een of ander manier met die kerk skakel. Die respondente bevestig egter dat baie van die kleiner gemeentetjies en informele kerke nie oor geboue beskik nie en dikwels nie vir hulself eredienste kan hou en op daardie manier die gemeenskap kan bedien nie. Die vraag of die kerk dan wel betrokke is en of die lidmate wel help is ook belangrik. Meeste respondente toon wel aan dat die kerk by hulle betrokke is en dat die kerk hulle help. Dit bevestig vroeëre navorsing wat gedoen is wat daarop dui dat ten spyte van die feit dat sommige individue van mening is dat die kerk nie genoeg doen nie, baie van die respondente in vorige navorsing daarop gedui het dat hulle juis nie die kerk sal verlaat nie al sou die kerk hulle nie help nie. Die positiewe gesindheid teenoor die kerk selfs die kleiner informele kerke, in die informele behuisingsgebiede word bevestig deur hierdie navorsing.

\section{Die kerk se betrokkenheid}

Respondente toon aan dat die kerk wel hulp verleen deur byvoorbeeld voedsel te verskaf. Die respondente vind veral die geestelike versorging van mense deur die kerk baie belangrik en is van mening dat die kerk op daardie manier 'n besondere bydrae lewer. Respondente het aangedui dat geestelike versorging van besondere betekenis is. Wat die verwagting van die kerk betref is daar ook verskillende verwagtinge gelys, waar verskeie respondente van mening is dat die kerk wel met kos en projekte moet help. Respondente het onder andere die opinie uitgespreek dat die kerk groepe moet stig waarin in mense se geestelike behoeftes voorsien kan word en mense gehelp kan word. Verskeie mense het aangedui dat die kerk sal moet verander deur meer aan projekte aandag te gee. Projekte is dus van besondere belang in hierdie gemeenskappe en die kerk sal ook in hierdie behoefte moet voorsien. 
Respondente het daarop gewys dat die kerk juis die kinders moet opvoed en die gemeenskap moet help sodat kinders saam met hul ouers kerk toe kan gaan en dat die kerk dan op sodanige wyse die armes kan help. 'n Respondent verklaar dat die kerk nie oor armoede verligting moet preek nie om die volgende rede: 'Nee, want as die kerk oor armoede preek sal die mense dink dat hulle ondermyn word'. Verskeie ander stem saam en dui onder andere aan dat die mense die kerk sal verlaat. ' $n$ Volgende respondent is van mening dat mense gehelp word 'deur vir hulle taxi's te kry om hulle huis toe te neem'. 'n Respondent het die opinie gelug dat mense geleer moet word om kinders kerk toe te bring. Op die vraag wat die kerk moet doen om mense te help, antwoord een respondent: 'Bid vir die mense om werk te kry'. 'n Volgende respondent is van mening dat die kerk moet betrokke raak deur '... ' $n$ groep te stig vir ouer mense wat nie werk het nie'.

Op die vraag: Wat moet die kerk doen? antwoord 'n respondent: 'Hulle moet ' $n$ groep vir volwasse mans stig en ook ' $n$ jeuggroep en hulle moet met al die mans in die omgewing praat sodat hulle hierdie saak kan bevorder'. Weereens is hy nie van mening dat daar oor armoede verligting gepraat moet word nie, want dit sal keer dat die mense kerk toe kom. Wat die toekoms betref, was die respondent se antwoord: 'As die jeug kan ophou om soos ouer mense op te tree en te leer hoe om dinge te doen'. 'n Ander respondent se opinie is dat die kerk die situasie kan verlig deur ' $n$ sokkerklub te begin en is weereens nie van mening dat die kerk oor armoede verligting moet preek nie, maar dat mense geleer moet word hoe om ryk te word. 'n Volgende respondent verklaar dat die kerk met die jongmense moet praat.

Wat die kerk kan doen om 'n beter situasie mee te bring sluit volgens respondente in dat die kerk moet ophou om ouer mense se geld te neem. Volgens een respondent kan kinders gehelp word om hulle skoolgelde te betaal en diegene wat sonder werk is, kan gehelp word om werk te verkry. Die kerk moet studiegroepe begin om mense te help, is die mening van een respondent.

Verder word sake genoem soos dat die kerk oor liefde sal preek en mense sal inspireer om hulle eie talente te ontwikkel. Bybelsverse moet gevind word om mense te help om saam te werk en om te deel. 'n Respondent het aangedui dat daar ernstig gebid moet word, want mense sterf van honger en moet gehelp word. Rykes moet gehelp word om tiendes te gee sodat die kerk gehelp kan word, word ook voorgestel. Huisbesoek om op grondvlak die situasie waar te neem word ook voorgestel, asook dat sopkombuise ingerig moet word.

\section{Die toekoms}

Ten opsigte van die toekoms van die gemeenskap is dit duidelik dat die respondente van mening is dat die regering self baie meer betrokke moet raak in die behoeftes van mense in die situasie. Mense moet eerlik met God en hulleself wees om 'n beter toekoms te verkry, dui een respondent aan. Mense moet geleer word om nie net te sit en te wag vir die toekoms nie, maar om self hand uit die mou te steek en te werk om 'n beter toekoms te bou, word voorgestel. Daar sal slegs ' $n$ beter toekoms wees as rykes hulle geheim deel van hoe hulle ryk geword het en deur ander te help. Vertroue op God kan 'n beter toekoms skep. Verskeie respondente is van mening dat 'n nuwe toekoms geskep kan word indien kerk en staat saamwerk.

\section{Hoe moet die mense op straat benader word?}

Om die navorsing sinvol te maak, was daar gepoog om deur die deelnemende aksie navorsing die kerk in die gemeenskap vanuit die response te inspireer om betrokke te raak by die mense op straat en die hele gemeenskap. Die kerk moet betrokke raak by die vreemdelinge vir die kerk in die gemeenskap. Die kerk se taak sal wees om diegene wat wel aan die kerk behoort so te inspireer dat hulle met ' $n$ kragtige verhouding tot God ook vanuit hoop 'n nuwe situasie kan skep in die informele behuisingsgebiede. Daarteenoor sal diegene buite die kerk benader moet word op so 'n wyse dat hulle wel betrokke sal raak by die kerk en ook dan sal bevestig dat die kerk wel vir hulle op 'n betekenisvolle wyse kan help. Die kerk sal op hierdie manier sinvolle bydrae kan lewer in die gemeenskap. Mense op straat kan nie ontmoet word deur die evangelie af te water nie. Die kern van die evangelie sal egter op so ' $n$ manier aangebied moet word en die mense op straat op so 'n kragtige manier benader word dat hulle die waarheid van die evangelie sal verstaan en respek vir die kerk sal verkry. Die kerk sal in die lig van die response heelwat aandag moet gee aan die geestelike behoeftes van mense in hierdie omgewing. Alhoewel die fisiese omstandighede soms haglik is, is dit so dat onder hierdie omstandighede ook 'n besondere behoefte en ' $n$ vraag na geestelike versorging is. Alhoewel die mense groot nood het aan voedsel, medisyne en klere is die omstandighede waarin hulle leef van so 'n aard dat die geestelike behoeftes ook na vore kom. Die kerk sal na die mense op straat moet uitreik; die kerk sal na al die vreemdelinge sy hande moet uitsteek om juis daardie persone geestelik te versorg en in die liefde van die evangelie te dra. Dit sal egter baie belangrik wees dat die kerk nie 'n skeiding maak tussen die geestelike behoeftes van al die mense en die nood waarin al die mense verkeer nie. ' $n$ Totale benadering van die mens in nood, veral die vreemdelinge vir die kerk is van groot belang en hier sal sekere duidelike riglyne gegee moet word. Die vreemdeling en swakke verdien die volle aandag van die kerk. Die mense op straat, wat soms as die vreemdeling op die pad van die kerk voorkom, moet dus met dieselfde respek behandel word as waarmee die vreemdeling in die Bybel behandel is. Die uitgangspunte vir die kerk is dus om juis ook self op straat teenwoordig te wees. Die kerk word dus nie beperk tot 'n gebou nie, maar word mense wat ook op straat lewe en ander mense op straat met die liefde en sorg van God inneem of terugneem in die gemeenskap van die geloof. Die kerk as gemeenskap van geloof word dan diegene wat juis met groot sorg omgee vir hulle wat hulle in die gemeenskap van die wêreld teëkom. Daar waar interaksie tussen kerk en wêreld plaasvind word die kerk die gemeenskap van 
hoop. Die mense op straat is dus nie 'n vyand nie, maar juis ook medereisigers wat omhels moet word deur die kerk. Die begrip vreemdeling in die Bybel open dus nog verdere moontlikhede vir die kerk se bediening in die wêreld. Deur die vreemdeling aan te raak met nuwe verwagtinge, kan die kerk mense op die rant van die samelewing betrek by die heil wat God gee. Die vreemdeling word die fokus van die kerk se bediening en die mense op straat word nie beskou as buitenstaanders nie, maar as mense wat bereik moet word met 'n boodskap van heil en verlossing. Sodoende verruim die kerk juis sy bestaan in die wêreld. Kerk en wêreld ontmoet, maar dit is juis 'n gesonde ontmoeting, waar die kerk mense op straat uitnooi tot nuwe lewe in God. In hierdie proses is die respek vir die mense op straat van groot belang en kan uit die respek wat vir die vreemdeling in die Bybel geld afgelei word dat die kerk ook respek vir die persoon op straat toon.

Die swakke in die gemeenskap sal ook besondere aandag moet geniet. Die kerk sal daarom die mense op straat moet benader met die wete dat verskeie van hulle ernstige siektes, onder andere MIV en Vigs, onder lede het. In die uitreik na hierdie mense sal daar steeds in gedagte gehou moet word dat hierdie siekte ' $n$ vernietigende effek op mense het en dat die kerk dan in hierdie opsig na hulle sal moet omsien. In die hantering hiervan sou die kerk in samewerking met ander genootskappe daarin kan slaag om mense te identifiseer wat tuis siek is en wat dan bepaalde hulp nodig het. Tekens van die liefde van God sal opgerig moet word.

Omgeegroepe moet gevorm word wat kan uitreik na mense in nood om vir hulle te sorg. Die diepe nood van mense kan alleen aangespreek word as hulle so gehelp word. Dit is al manier waarop die kerk werklik as gebroke kerk heling kan bring in hierdie wêreld van gebrokenheid, Die kerk sal dus nie van bo af 'n struktuur afdwing op die gemeenskap nie, maar sal vanuit die gemeenskap self soek na wyses waarop die gemeenskap gehelp kan word en waarop die verskillende strukture saam kan werk om die gemeenskap op te bou.

Die kerk is nie die kerklike strukture soos die geboue nie, maar dit neem nie weg dat sulke strukture wel heilsaam kan wees nie. Die kerklike gemeenskappe sal hulle moet beywer om saam by plaaslike owerhede en ander owerhede aansoek te doen vir bepaalde gebiede in die informele behuisingsgebiede, waarin hulle dan wel sekere strukture sou kan oprig wat hulle saam sal kan gebruik. Deur saam te werk sou byvoorbeeld crèches, opvoedingsgeleenthede en selfs bepaalde vorme van naskoolse onderrig en onderrig in geletterdheid vir mense gegee kon word. Die groot behoefte in die informele gebiede is dat die gemeenskappe werklik gehelp kan word om strukture op te rig waar hulle dan wel nie slegs Sondae eredienste sou kon hou nie, maar waar hulle in die res van die week ook na mense sou kon omsien deur middel van versorging en die voorsiening van behoeftes van mense in die gemeenskap. Dit sal beteken dat in informele gebiede verskillende kerkgenootskappe bereid sal moet wees om hande te vat en saam betrokke te raak by die gemeenskap deur te vra op watter wyse hulle die gemeenskap die beste kan dien. Douglas (2006) skryf in dié verband:

Careful analysis is required to ascertain the complex social, economic and political controls of peri-urban life and environmental change. Often the influence of the rich and powerful is only part of the picture. Subtle intra-group dynamics among the deprived and powerless can be significant in deciding if projects, whether locally inspired or externally supported, succeed and become sustainable. ['n Deeglike analise is nodig om te bepaal watter beheermaatreëls die komplekse sosiale, ekonomiese en politieke aspekte van die peri-stedelike lewe en omgewingsverandering bepaal. Die invloed van die rykes en magtiges is duidelik slegs deel van die verhaal. Die subtiele intergroepsdinamika tussen die minderbevoorregtes en die magteloses kan ' $n$ belangrike deel uitmaak van die saak of projekte, hetsy plaaslik geïnspireerd of van buite ondersteun, slaag en volhoubaar is.]

(Douglas 2006:26)

Wat projekte betref, sou die verskillende genootskappe en kerke ook bymekaar aansluiting kon vind. Die hantering van projekte deur onder andere die MUCCPP (Manguang University of the Free State Community Partnership Programme) in Bloemfontein is van besondere betekenis. Kleiner gemeentetjies sou kon inskakel by hierdie projekte wat op 'n groter skaal poog om in die gemeenskap hulp te verleen. Op daardie manier sou die gemeenskap gehelp kon word en sou opbou werk dan verder gedoen kan word. Selfs sodanige projekte moet veral daarop gerig wees om mense wat op ' $n$ baie basiese vlak in hul samelewing leef te help om ook selfonderhoudend te wees deur onder andere tuinbouprojekte, hoenderteelprojekte en ook ander projekte waarin op baie klein skaal op 'n baie klein gebied wel selfversorgend opgetree kan word.

'n Ander saak wat sterk na vore kom uit hierdie respondente se antwoorde is die vraag hoe die gemeenskap ook gehelp kan word om met die regering te skakel. Die regering van die dag en die owerhede van die dag het 'n groot verantwoordelikheid teenoor die mense in informele gebiede. Dit is nou reeds duidelik dat informele gebiede nie net eenvoudig oornag gaan verdwyn nie. Hierdie gebiede is, inteendeel, besig om te groei. Die owerhede sal daaraan aandag moet gee om betrokke te raak by die gemeenskappe in die informele gebiede. Mukhija (2003) skryf:

I believe that there is a more imaginative way of conceptualizing housing improvement and squatters as developers. It is difficult for the slum-dwellers in Mumbai, or in any other city, to be developers, in the narrow sense without merely being codevelopers in a misleading nominal manner. Squatters should be the developers in the sense of controlling decision-making, deciding the housing improvement approach, and capturing a key share of increased value of land. [Ek glo dat daar ' $n$ meer verbeeldingryke manier is om behuisigsverbeterings te konseptualiseer en plakkers as ontwikkelaars voor te stel. Dit is moeilik vir die 'slum'bewoners in Moembaai of enige ander stad om self ontwikkelaars eerder as om bloot mede-ontwikkelaars op ' $n$ misleidende of nominale wyse te wees. Plakkers moet ontwikkelaars wees in die sin dat hulle besluite beheer, die behuisingsverbeterings bepaal, en 'n belangrike deel van die verhoogde waarde van die grond verkry.]

(Mukhija 2003:142) 
Alle ontwikkeling moet menslik wees en die individu in ag neem (Hazel \& Parry 2004:187). Swanepoel (2002) skryf:

No physical development can be divorced from the person and no human development can be divorced from the physical. All development must have a single focus. The focus is the human being. [Geen fisiese ontwikkeling kan geskei word van die persoon nie en geen menslike ontwikkeling kan geskei word van die fisiese nie. Alle ontwikkeling moet 'n enkele fokus hê. Die fokus is die mens.]

(Swanepoel 2002:3)

Die gemeenskap in die informele behuisingsgebiede moet ook begelei word na welsyn:

Livelihood strategies used by an individual or household that have positive outcomes will mean that vulnerability to outside shocks is reduced. An individual or household will then be more resilient to changes in the external environment. The term well-being is used as a relative measure of how vulnerable or resilient people are within the urban environment. Therefore vulnerability and resilience are at opposite sides of the measure for well-being. [Lewensbestaan-strategieë wat deur ' $n$ individu of huishouding aangewend word en wat positiewe gevolge het, sal beteken dat die kwesbaarheid teen skokke van buite verminder word. Die individu of huishouding sal dan meer veerkragtig in die hantering van verandering in die eksterne omgewing wees. Die term welwese word gebruik as ' $n$ relatiewe maatstaf van hoe kwesbaar of veerkragtig mense binne die stedelike omgewing is. Daarom staan kwesbaarheid en veerkragtigheid teenoor mekaar ten opsigte van die maatstaf van welwese.]

(Nomdo 2002:196)

\section{Slotsom}

Die uitdaging vir die kerk in die informele gebiede bly besondergroot. Selfs menseop straat kykna diekerk virleiding om armoede en nood te verlig en om geestelike behoeftes te hanteer. Op grondvlak sal kerklike gemeenskappe juis saam moet optree om die uiterste omstandighede te hanteer. Die kerk sal getroue navolgers van Jesus Christus moet wees.

\section{Literatuurverwysings}

Allen, L.C., 1990, Ezekiel 20-48 [Esegiël 20-48], Word Biblical Commentary 29. Word Books, Dallas, Texas.

Altrichter, H., Kemmis, S., McTaggart, R. \& Zuber-Skerritt, O., 2002, 'The concept of action research' [Die konsep van aksie navorsing], The Learning Organisation 9(3), 125-131.

Cassidy, R.J., 2001, Paul in Chains: Roman imprisonment and the letters of St. Paul [Paulus in kettings: Romeinse gevangenisstraf en die briewe van St. Paulus], Herder and Herder, New York.

Coetzee, E., 2002, 'Urban vulnerability: A conceptual framework' [Stedelike kwesbaarheid: ' $n$ Konseptuele raamwerk], in C. Nomdo, \& E. Coetzee (eds.), Urban vulnerability: Perspectives from Southern Africa, pp. 2-27, Periperi, Rondebosch, Cape Town.

Douglas, I., 2006, 'Peri-Urban ecosystems and societies: Transitional zones and contrasting values' [Peri-stedelike ekosisteme en samelewings: Oorgangssones en kontrasterende waardes], in D. McGregor, D. Simon \& D. Thompson, The PeriUrban interface: Approaches to sustainable natural and human resources, pp. Urban interface: Approaches
313-325, Earthscan, London.
Durham, J.I., 1987, Exodus [Eksodus], Word Biblical Commentary 3, Word Books, Waco, Texas.

Elliott, E., 1995, Liberating Paul: The justice of God and the politics of the apostle [Om Paulus te bevry: Die geregtigheid van God en die politiek van die apostel]. Sheffield Academic Press, Sheffield.

Guthrie, D., 1981, New Testament Theology [Nuwe Testament Teologie]. InterVarsity, Leicester.

Harris, R.L., 1990, Leviticus [Levitikus]. Expositor's Bible Commentary Vol. 2, Zondervan, Grand Rapids.

Hartley, J.E., 1992, Leviticus [Levitikus]. Word Biblical Commentary 4, Word Books, Dallas, Texas.

Hazel, G. \& Parry, R., 2004, Making cities work [Om stede te laat werk]. WileyAcademy, Chichester.

Kalland, E.S., 1992, Deuteronomy [Deuteronomium]. Expositor's Bible Commentary Vol. 3, Zondervan, Grand Rapids.

Kim, S., 2002, Paul and the new perspective: Second thoughts on the origin of Paul's Gospel [Paulus en die nuwe perspektiewe: Tweede gedagtes oor die oorsprong van Paulus se evangelie]. Eerdmans, Grand Rapids, MI.

Liefeld, W.L., 1984, Luke [Lukas]. Expositor's Bible Commentary Vol. 8, Regency, Grand Rapids.

Melao, L.N., 2003, Guidelines that determine low-income housing plot sizes and layouts: a case study of Mahpikela (Batho Location), and Bloemanda in the Mangaung Residential area [Riglyne wat die lae-inkomste behuising en uitleg bepaal: ' $n$ Gevallestudie van Mahpikela (Batho Lokasie) en Bloemanda in die Mangaung Residensiële gebied]. Unpublished MA-Dissertation, University of the Free State.

Miller, P., 1990, Deuteronomy [Deuteronomium]. Interpretation: A Bible commentary for teaching and preaching. John Knox, Louisville.

Mokoena, M. \& Marais, L., 2008, 'An evaluation of post-apartheid housing delivery in Mangaung: A view from local government' ['n Evaluasie van post-apartheid behuising lewering in Mangaung: 'n Perspektief van plaaslike regering] in L.Marais, \& G. Visser (eds.), Spatialities of urban change: Selected themes from Bloemfontein at the beginning of the 21st century, pp. 97-114, SUN MeDIA Stellenbosch.

Mukhala, E. \& Groenewald, D.C., 1998, 'Experiences and perceptions of black small-scale irrigation farmers in the Free State' [Ervarings en persepsies van Swart klein-skaal besproeiing boere in die Vrystaat], Suid-Afrikaanse Tydskrif vir Lwart klein-skaal besproeiing
Landbouvoorligting $27,1-18$.

Mukhija, V., 2003, Squatters as developers: Slum redevelopment in Mumbai [Plakkers as ontwikkelaars: 'Slum' herontwikkeling in Moembaai]. Ashgate, Aldershot.

Nieuwenhuis, J., 2007, 'Analysing qualitative data' [Om kwalitatiewe inligting te analiseer], in K. Maree (ed.), First steps in research, Van Schaik, Pretoria.

Nolland, J., 1989, Luke 1-9:20 [Lukas 1-9:20], Word Biblical Commentary 35A, Word Books, Dallas, Texas.

Nomdo, C., 2002, 'Conclusion' [Gevolgtrekking] in C. Nomdo \& E. Coetzee (eds.), Urban vulnerability: Perspectives from Southern Africa, pp. 195-207, Periperi, Rondebosch, Cape Town.

Patton, M.Q., 2002, Qualitative research and evaluation methods [Kwalitatiewe navorsing en evaluasie metodes], 3rd edn., Sage, London.

Schreiner, T.S., 2001, Paul: Apostle of God's glory in Christ. A Pauline theology [Paulus: Apostel van God se glorie in Christus. 'n Pauliniese teologie], InterVarsity, Downers Grove, III.

Smith, R.L., 1984, Micah-Malachi [Miga-Maleagi], Word Biblical Commentary 32, Word Books, Waco, Texas.

Swanepoel, H., 2002, Community development: Putting plans into action [Gemeenskapsontwikkeling: Om planne in aksie te sit], 3rd edn., Juta. Lansdowne.

Swanepoel, H. \& De Beer, F., 2006, Community development: Breaking the cycle of poverty [Gemeenskapsontwikkeling: Om die siklus van armoede te verbreek], 4th edn., Juta, Lansdowne.

Tacoli, C., McGranahan, G. \& Satterthwaite, D., 2008, 'Urbanization, poverty and inequity: Is rural-urban migration a poverty problem, or part of the solution" [Verstedeliking, armoede en ongelykheid: Is plattelandse-stedelike migrasie ' armoese probleem of deel van die oplossing?] in G. Martine. G. McGranahan, poverty and environment in the 21 st century, pp. 37-54, Earthscan, London. 